\title{
ЮРИСПРУДЕНЦИЯ
}

DOI: 10.17805/ggz.2018.4.7

\section{Некоторые аспекты соотношения греха и преступления}

И. И. Голубов

Московский гуманитарный университет,

М. В. Денисенко

Московский университет МВД РФ им. В. Я. Кикотя

В статье обращается внимание на значение христианства в формировании основных принципов и институтов уголовного права, в том числе преступления и наказания. Выявлены и показаны некоторые сходные признаки, а также различия греха и преступления. Сделан вывод о различной природе греха и преступления. Отмечается, что духовное возрождение ценностей, не запрещенных законом религиозных конфессий, в значительной степени будет способствовать снижению уровня преступности.

Статья подготовлена на основе доклада на Всероссийской научной конференции «Моисеевские чтения» (Москва, 26 июня 2018 г.).

Ключевые слова: религия; уголовный закон; христианство; грех; преступление

\section{Some Aspects of the Correlation between Sin and Crime}

I. I. Golubov

Moscow University for the Humanities,

M. V. Denisenko

Kikot Moscow University of the Ministry of

Interior Affairs of the Russian Federation

The article examines the significance of Christianity in the development of the basic principles and institutions of criminal law, including crime and punishment. The authors identify and show some similar features, as well as the differences between sin and crime. They draw a conclusion on the different natures of sin and crime. It is noted that the spiritual revival of values that are not prohibited by laws of religious denominations will greatly contribute to reducing the crime rate.

The article comprises the main points of the report presented at the allRussian conference "Moiseev Readings" (Moscow, June 26, 2018).

Keywords: religion; criminal law; Christianity; sin; crime 
Влияние религии на все сферы жизни человека можно назвать аксиомой, не требующей доказательств или ссылок на какие-либо источники. Не является исключением и область юриспруденции, на что однозначно указывалось еще в посланиях Святых Апостолов христианской церкви: «...c переменою священства необходимо быть перемене и закона» (Евр. 7:12).

Явления, выступающие в качестве предмета настоящей статьи (соотношение греха и преступления), будут рассмотрены исходя из положений христианства - одной из основных мировых конфессий. Тем более что христианская духовная традиция тесно взаимосвязана с другими основными религиями - как историческими основами вероучения, так и базисными догматами (Мировые религии ..., 2013: 4). При этом следует отметить неоспоримость вклада всех традиционных религий в формирование основных современных мировых правовых систем, на что обоснованно обращается внимание в современных трудах, посвященных изучению соотношения религии и права (там же: 5).

Следует отметить, что изучение соотношения обозначенных в названии статьи явлений не является новинкой для российской юридической мысли. Серьезные и столь необходимые, по мнению авторов данной статьи, исследования по вопросам соотношения религии и уголовного права в конце прошлого и начале нынешнего тысячелетий проводились А. А. Тер-Акоповым, А. А. Толкаченко, К. В. Харабетом, авторскими коллективами под их руководством, Н. В. Акимовой, Г. И. Загорским, Г. В. Мальцевым, О. А. Мозговым, Ю. А. Зюбановым и другими авторами. Этой же тематике была посвящена достаточно обширная дореволюционная литература (Христианское учение ..., 2009: 6).

Рассмотреть все аспекты соотношения греха и преступления в рамках одной статьи невозможно, поэтому авторами будут затронуты лишь некоторые из них.

Итак, не одно тысячелетие минуло со времен событий, отображенных в Ветхом и Новом заветах. И все это время человечество соотносило с ними принимаемые законы, о чем свидетельствует вся история права. Нельзя не согласиться с утверждением о том, что религиозные заповеди были первыми законами, установлением границ непреступного поведения, переход через которые грозил человеку физическим исчезновением (Кондратюк, 2001: 10). Такого же мнения придерживался и Ш. Л. Монтескье, указывавший на то, что «религия имеет свои уголовные законы» (Монтескье, 1999: 402).

Влияние основных христианских догматов, в том числе и учения о грехе, на содержание современного уголовного законодательства бесспорно, на что неоднократно указывалось в публикациях по рассматриваемой тематике 
(Дворникова, 2009; Христианское учение ... , 2009; Левакин, 2012; Мировые религии ... , 2013; Осипян, 2014; Акимова, 2015).

Можно согласиться с утверждением о том, что мы имеем возможность оценить значение того или иного института уголовного права для современности только в том случае, если знаем его исторические корни (Виденькина, Денисенко, 2015). Без оценки того, что было, вряд ли возможна объективная оценка того, что имеется ныне (Ляпунов, 2006: 9).

Такую постановку вопроса следует признать верной, поскольку священные писания любой из традиционных религиозных конфессий существуют уже множество веков и, безусловно (исходя из указанных временных, а также статистических данных о количестве верующих), являются самыми читаемыми в настоящее время.

Итак, грех (греч. amartia - ошибка, промах, мимо цели) - повреждение человеческой природы, болезнь души. Как пишет Л. В. Кондратюк, «грех как первичное качество человеческой духовности может рассматриваться как малодушный отказ человеческого духа от стремления к высшему - трансценденции, как бытийная слабость» (Кондратюк, 2001: 8).

В христианстве грехи классифицируются следующим образом: первородное повреждение (грехопадение Адама); родовое повреждение (грехи предков); личный грех человека. Именно из-за греха Адама (гордыни) человеку свойственны смертность, тленность и страстность. При этом конкретный человек за него не отвечает. За родовое повреждение также нет ответственности у человека. Однако родовое повреждение означает передачу склонности к страстям (и, соответственно, к определенного рода грехам) по наследству.

Святоотеческое учение также содержит указание на «личный грех». Именно его проявления закреплены в нормах Особенной части УК РФ в качестве преступлений. И за него человек должен и будет отвечать: в миру, согласно УК РФ (если его виновность в установленном законом порядке будет доказана), и по ту сторону мирского бытия (тут уж в обязательном порядке).

Согласно святоотеческому учению, внешнее проявление греховности человека - преступления - это следствия, а не причины. Причина плохих поступков, в том числе и преступлений - в грехе. Таким образом, грех и преступление имеют различную природу. В то время как грех рождается в сердце человека, преступление - это его внешнее выражение. Получается, что грех лежит в основе преступления, является основанием и причиной его совершения. Соответственно грех и преступление можно соотнести как причину и внешнее следствие.

Изложенные святоотеческие положения нашли свое отражение и в криминологических исследованиях. Так, в послевоенной отечественной кри- 
минологии середины XX в. получила развитие концепция, в соответствии с которой причины преступности лежат в сфере сознания человека. Н. Ф. Кузнецова в своих работах, в частности, отмечает, что непосредственной причиной преступлений является субъективный фактор, к которому следует отнести в том числе и дефекты психологии индивидуумов (Кузнецова, 1984). Исследовательница приходит к выводу о социально-психологическом содержании причин преступлений (Криминология, 1998: 50). И это несмотря на то, что указанная концепция противоречила фундаментальному положению материалистической философии о первичности бытия и вторичности сознания, а также подвергалась в советское время критике (Осипов, 1978: 47-48).

Рассматривая вопрос о соотношении греха и преступления, нельзя не вспомнить о таком понятии, как безнравственное деяние, поскольку правовые нормы о преступлении, религиозные догматы о греховном и нравственные нормы тесно взаимосвязаны друг с другом, что не требует отдельного обоснования. В связи с этим представляет интерес мнение известного русского ученого-криминалиста Н. С. Таганцева, отмечавшего, что область греховного шире области преступного; при этом понятия греха, безнравственного поступка и преступления имеют «не покрывающие друг друга» области (Таганцев, 1994: 26, 27).

Соглашаясь с точкой зрения о более широком объеме области греховного, позволим высказать предположение о том, что каждое предусмотренное в УК РФ преступление относится к области греховного, т. е. является личнылм грехом.

При этом грех — с одной стороны, а преступление и безнравственный проступок - с другой, безусловно, имеют различную природу. В связи с чем, соотносить обозначенные нами понятия в одной плоскости было бы некорректным. Различия в природе между этими понятиями заключены в том, что безнравственными (как и преступными) могут быть только внешние поступки человека. А греховными могут быть и помыслы, которые впоследствии порождают безнравственные и (или) преступные поступки, поскольку понятие греховности не только шире, но и объемнее двух других рассматриваемых понятий.

Таким образом, представляется возможным высказать предположение о том, что грех является родовым понятием по отношению к безнравственным и преступным деяниям, одновременно представляя собой их причину. T. е., если грех возникает и существует внутри человека (исходит из сердца), то порождаемое им преступление является внешним выражением греха в физическом мире. 
Подтверждением сказанного является и мнение Святых Отцов, высказывавшихся о том, что грехом является противление заповедям Божиим; а также отмечавшим, что грех есть извращение порядка бытия в мире духовном и физическом (Кронштадский, 2014: 25). Тем самым Святые Отцы включали в содержание греховности и преступления.

Святой Ефрем Сирин указывал на то, что греховными помыслами производится все худое (Ефрем Сирин, 1992: 390). В этом высказывании под термином «худой» также явно просматривается преступление.

Изложенное подтверждается и в трудах современных криминологов. Так, Л. В. Кондратюк отмечает, что христианство связывает грех с поврежденностью духовной сферы человека, при этом высказывая мнение о том, что причины преступности укоренены в несовершенстве духовной природы человека (духовной поврежденности), в его греховности (Кондратюк, 2001: 10, 14).

Еще одним аргументом в пользу высказанного предположения о греховности всякого преступного деяния является твердая позиция святоотеческого учения, в котором говорится о том, что каждый христианин обязан подчиняться действующей власти и исполнять светские законы.

Так, Апостол Павел в Послании к римлянам указывал: «Всякая душа да будет покорна высшим властям, ибо нет власти не от Бога; существующие же власти от Бога установлены. Посему противящейся власти противиться Божию установлению. А противящиеся сами навлекут на себя осуждение. Ибо начальствующие страшны не для добрых дел, но для злых. Хочешь ли не бояться власти? Делай добро, и получишь похвалу от нее, ибо начальник есть Божий слуга, тебе на добро. Если же делаешь зло, бойся, ибо он не напрасно носит меч: он Божий слуга, отмститель в наказание делающему зло. И потому надо повиноваться не только из страха наказания, но и по совести. Для чего Вы и подати платите, ибо они Божии служители, сим самым постоянно занятые. Итак, отдавайте всякому должное: кому подать, подать; кому оброк, оброк; кому страх, страх; кому честь, честь» (Библия, 2007: 1240).

Эту же мысль высказывает и Апостол Петр: «Итак, будьте покорны всякому человеческому начальству, для Господа: царю ли, как верховной власти, правителям ли, как от него посылаемым для наказания преступников и для поощрения делающих добро, - ибо такова есть воля Божия, чтобы мы, делая добро, заграждали уста невежеству безумных людей» (там же: 1211). Господь даже советует молиться за «царей и за всех начальствующих, дабы проводить нам жизнь тихую и безмятежную во всяком благочестии и чистоте, ибо это хорошо и угодно Спасителю нашему Богу» (там же: 1300). 
Иеромонах Иов (Гумеров) говорит, что Библия учит исполнять законы той страны, в которой человек живет и подчиняется правителям, независимо от их достоинства или недостатков.

В качестве внутренних сходных признаков греха и преступления следует обратить внимание на то, что как грех, так и преступление присущи только человеку как биологическому виду и существу общественному. Исходя из сути как греха, так и преступления, приходим к выводу, что вне общества нет ни первого, ни второго.

В результате соотношения понятий «грех» и «преступление» представляется возможным прийти к выводу о том, что по своей субъективной стороне (т. е. по отношению к содеянному) и грех и преступление также имеют существенное сходство.

К такому заключению следует прийти по следующим основаниям:

1) согласно ч. 1 ст. 14 УК РФ, преступлением признается виновно совершенное общественно опасное деяние, запрещенное УК РФ под угрозой наказания;

2) согласно ст. 5 УК РФ, лицо подлежит уголовной ответственности только за виновно совершенное деяние; объективное вменение, т. е. уголовная ответственность за невиновное причинение вреда не допускается.

В связи с этим примечателен ответ Иисуса Христа фарисеям относительно виновности в грехе: «...если бы вы были слепы, то не имели бы на себе греха; но как вы говорите, что видите, то грех остается на вас» (Ин. 9:41). Тем самым Иисус Христос дает понять, что ответственность за грех наступает только при условии осознания его человеком, т. е. за его виновное совершение.

Святой Василий Великий на Пятом Вселенском Соборе христианской церкви (553 г., г. Константинополь) в качестве условия совершения греха указывал на свободу воли человека. Только если есть у человека выбор он может совершить грех. И только такое деяние влечет необходимость его искупления.

В некоторых христианских конфессиях получил распространение такой термин, как «первородный грех». Здесь имеется в виду личный грех Адама, нарушившего запрет Господа, который якобы распространяется на всех людей. Но это противоречит первоначальной христианской концепции о свободе воли. И, выражаясь уголовно-правовым языком, означает объективное вменение, поскольку согласно указанной посылке все люди с момента рождения уже повинны в том, чего не совершали. Это, по меньшей мере, нелогично. Даже с учетом учения Блаженного Августина, согласно которому от первородного греха человека освобождает обряд крещения. 
Пятый Вселенский Собор осудил такую трактовку личного грехопадения Адама, в результате чего человек получил смертность, тленность и страстность, поскольку ни смертность, ни тленность, ни страстность преступлениями не является. Это проявления природы человека. Именно поэтому Святой Василий Великий назвал падение Адама «родовым повреждением» человеческой природы, а не родовым грехом.

Таким образом, в этом родовом повреждении человеческой природы находятся истоки причинного комплекса преступности (страсти, которые порождают грех, а вместе с ним и преступление). Для преступления же характерна свобода выбора, это виновное причинение вреда охраняемым уголовным законом общественным отношениям.

Итак, следует подытожить некоторые высказанные мысли:

1. Грех и преступление по своему содержанию обладают рядом сходных свойств и характеристик. При этом все преступления являются греховными, однако не все грехи преступны.

2. Грех и преступление имеют различную природу. В то время как грех рождается в сердце человека, преступление - это его внешнее выражение.

3. Грех лежит в основе преступления, является основанием и причиной его совершения. Грех и преступление можно соотнести как причину и внешнее следствие.

Духовное возрождение религиозных ценностей, не запрещенных законом религиозных конфессий, о которых шла речь в начале статьи, в значительной степени будет способствовать снижению уровня преступности.

\section{СПИСОК ЛИТЕРАТУРЫ}

Акимова, Н. В. (2015) Влияние христианства на развитие институтов преступления и наказания в России // Журнал российского права. № 10. С. 92-98.

Библия (2007) : Священное Писание в Синодальном переводе. М. : Рос. Библейское об-во. 1312 с.

Виденькина, Ж. В., Денисенко, М. В. (2015) Социально-историческая обусловленность выделения преступного сообщества как формы соучастия // Закон и право. № 6. С. 112-116.

Дворникова, О. А. (2009) Религия и закон: проблемы взаимодействия // Журнал российского права. № 7 (151). С. 45-58.

Кондратюк, Л. В. (2001) Антропология преступления (микрокриминология). М. : Норма. 336, [1] с.

Криминология (1998) / под ред. Н. Ф. Кузнецовой. М. : Зерцало. 150 с. 
Кронштадский, Иоанн, Святой праведный. (2014) Правда о Боге, мире и человеке. М. : Сибирская Благозвонница. 363 с.

Кузнецова, Н. Ф. (1984) Проблемы криминологической детерминации / под ред. В. Н. Кудрявцева. М. : Изд-во Моск. ун-та. 208 с.

Левакин, И. В. (2012) Право и религиозно-нравственные нормы российского общества // Журнал российского права. № 6 (186). С. 97-106.

Ляпунов, Ю. И. (2006) Уголовный кодекс Российской Федерации 1996 года: достоинства и недостатки // Уголовному кодексу Российской Федерации 10 лет (итоги и перспективы) : сб. науч. статей / под ред. Н. Г. Кадникова. М. : МосУ МВД РФ. 232 с. С. 7-15.

Мировые религии о преступлении и наказании (2013) / науч. ред.: А. А. Толкаченко, К. В. Харабет. М. : РИПОЛ классик. 608 с.

Монтескье, Ш. Л. (1999) О духе законов. М. : Мысль. 674 с.

Осипов, П. П. (1978) Понятие общих причин преступности // Комплексное изучение системы воздействия на преступность / под ред. доц. П. П. Осипова. Л. : Изд-во ЛГУ. 150 с. С. 50-68.

Осипян, Б. А. (2014) Религиозные измерения национального законодательства // Гражданин и право. № 7. С. 32-41.

Ефрем Сирин, Св. (1992) Творения : [в 2 т.]. М. : Посад. Т. 2. 430, II с.

Таганцев, Н. С. (1994) Русское уголовное право: Лекции. Часть общая : в 2 т. М. : Наука. Т. 1.380 с.

Христианское учение о преступлении и наказании (2009) / науч. ред.: К. В. Харабет, А. А. Толкаченко. М. : Норма. 336 с.

Дата поступления: 10.07.2018 г.

Голубов Игорь Иванович - кандидат юридических наук, доцент, профессор кафедры уголовно-правовых и специальных дисциплин Московского гуманитарного университета. Тел.: +7 (903) 668-10-90. Эл. адрес: igolubov@yandex.ru

Golubov Igor Ivanovich, Candidate of Law, Associate Professor; Professor, Department of Criminal, Legal and Special Disciplines, Moscow University for the Humanities. Tel.: +7 (903) 668-10-90. E-mail: igolubov@yandex.ru

Денисенко Михаил Вячеславович - кандидат юридических наук, доцент, доцент кафедры уголовного права Московского университета МВД РФ им. В. Я. Кикотя. Тел.: +7 (963) 750-83-85. Эл. адрес: m.denisenko@list.ru 
Denisenko Mikhail Viacheslavovich, Candidate of Law, Associate Professor, Department of Criminal Law, V. Ya. Kikot Moscow University of the Ministry of Interior Affairs of the Russian Federation. Tel.: +7 (963) 750-83-85. E-mail: m.denisenko@list.ru

Для циитирования:

Голубов И. В., Денисенко М. В. Некоторые аспекты соотношения греха и преступления [Электронный ресурс] // Горизонты гуманитарного знания. 2018. № 4. C. 143-151. URL: http://journals.mosgu.ru/ggz/article/view/849 (дата обращения: дд.мм.гггг). DOI: 10.17805/ggz.2018.4.7 